\title{
THE BOTTOM LINE
}

\section{Partha Kar: Stan Lee's lessons for the NHS}

\author{
Partha Kar consultant in diabetes and endocrinology \\ Portsmouth Hospitals NHS Trust
}

Last month the world lost Stan Lee, the great comic book creator. I was one of many who mourned his loss. As a child I loved the colourful panels and stories of heroism in comic books, and as I've grown older I've become aware of some important life lessons they've taught me. Those lessons-around management, leadership, and equality - are ever more important as the NHS faces an uphill struggle to maintain staff morale.

For one thing, comic books help us understand our colleagues by creating vivid characters who personify specific personality types. Personality types have been mapped, eruditely but controversially, by Myers-Briggs scores and other measures. But comic book characters can help us to understand these types and imagine how they would act in different situations.

We've all met someone who stands up for what's right and whose reluctance to shift on principles frustrates others, just as it does with Superman and Captain America. And we've all met the show-off who struggles to fit into a team but still fights the good fight, just as Batman and Iron Man do.

Beyond this, comic book stories are full of big egos burying hatchets-people recognising their own weaknesses and collaborating for the sake of a team, such as the Avengers or the Justice League. And yet, how many times has integration in the NHS faltered at a presentation meeting, simply because different personalities can't work together?

Certain circumstances need someone else-some other character-to step forward and take the lead
Thinking about how fictional characters overcome their differences has helped me in my work. When creating a model of integrated care in Portsmouth and building consensus in my role at NHS England I was aware that certain circumstances needed someone else-some other character-to step forward and take the lead. It was about the team achieving the goal.

Similarly, the NHS may have introduced mandatory courses on equality and diversity, but these often falter when it comes to delivery. In the X-Men series, created in the 1960s to highlight prejudice against certain groups, "mutants" are accepted rather than shunned, and their capabilities are recognised. The release of the Black Panther film in 2018 showed many children that being a superhero wasn't about being white-it was about their skills and qualities. In terms of gender, studios aren't merely paying lip service to diversity when they give prominent female title roles to Wonder Woman or Captain Marvel: these women are central figures who become leaders because of their abilities. People say that life imitates art. The NHS would certainly be a better place if we could learn how to work together and use the skills of the whole team, like the superheroes we know and admire.

Competing interests: I am associate national clinical director for diabetes with NHS England, leading on digital innovation.

Provenance and peer review: Commissioned; not externally peer reviewed.

Published by the BMJ Publishing Group Limited. For permission to use (where not already granted under a licence) please go to http://group.bmj.com/group/rights-licensing/ permissions 